\title{
John Milton’s Ongoing Project of Protestant Enlightenment in Paradise Lost
}

\author{
WANG Su-fang \\ National Cheng-Kung University, Tainan, Taiwan
}

\begin{abstract}
For some critics, the publication of Milton's Paradise Lost in 1667 suggests his taking religious retreat from his previous political investment in both the Commonwealth Government (1649-1653) and Oliver Cromwell's Protectorate that was abnegated by the return of King Charles II in 1660. Not to mention that Milton’s flamboyant portrayal of Satan appears to be a critique of republicanism: Just as the republicans who revolted against the monarchy, Satan tempts other angels to rebel against the omnipotent God and gain their freedom. This transgressive betrayal fails and is punished in Paradise Lost. However, when the strict censorship of the writings of Milton's contemporaries is taken into account, the strategies employed in Milton’s Paradise Lost become clearer: It may be read as a veiled critique of kingship hiding behind the façade of a criticism of republicanism so as to circumvent censorship. In other words, the work may have surreptitiously conveyed a hidden message for his English citizens. That message may be indirectly delivered through Milton's innovative elaboration of the fall of Man, which is roughly described in the Genesis. Therefore, this essay argues that Milton veils the seed of political reform in the moral lessons conveyed in his presentation of the psychological dynamic of Adam and Eve's fall. In addition, this essay further explores how Milton endeavors to re-shape the national consciousness of the 17th century English people through alternate historical awareness.
\end{abstract}

Keywords: the fall of Adam and Eve, free will, fortitude

\section{Introduction}

To his political rivals, especially the defenders of Charles II's regime, John Milton's world-renowned claim to be undertaking to "justify the ways of God to man" in the opening of Paradise Lost (henceforth, PL), marked a retreat from the political battlefield and his seeking religious consolation instead (Milton, 2005, p. 4). Milton had been long recognized as a vehement political activist, taking part in the post-civil war republican institution of Oliver Cromwell's Protectorate. Milton once served as Latin Secretary, delivering several outstanding but controversial pamphlet tracts regarding anti-prelatic issues, the free press and divorce as well as defending the Revolution and regicide shortly before the Restoration in The Ready and Easy Way (1660). Now, by shifting his focus to religion issues, Milton appeared to his political and Catholic opponents to have returned to embracing his earlier cause of Protestantism. Blair Worden, a modern critic, also concurs with this reading, arguing that Milton "withdraws from politics into faith” (as cited in Walker, 2006, p. 189).

Nonetheless, a mere religious reading of $P L$ would see superficial when we take into account Milton's politico-literary ambitions and the political milieu of the Restoration. Milton explicitly declared in 1642 that he

WANG Su-fang, Ph.D. Candidate, Department of Foreign Languages and Literature, National Cheng-Kung University. 
aspires to be a national poet, not merely a religious poet, in the introduction to Book II of The Reason of Church-Government: His purpose is to promote "God's glory by the honour and instruction of my country" (as cited in Stevens, 2001, p. 254). In PL, he adapts epic conventions to a Christian subject after forsaking his past project of following in Spenser's steps by writing about the national cult figure, King Arthur (Teskey, 2005, p. xviii). The authorities labeled Milton a dissenter after his having gone through the hardship of being put into prison and enduring a long term of hiding from further political suppression. Under the rigid censorship of the time, all of his writing would have been meticulously scrutinized by the authorities concerned. As critic Quint (1993) speculates, Milton's indirect and allusive criticism of the Stuart kings "was no doubt conditioned by the problem of censorship” (p. 269). In cautious defiance, Milton veiled his critique of kingship in a seeming critique of republicanism, represented by Satan (this will be discussed in depth later).

According to Teskey, Milton started to write PL sometime in 1658 and had it published in 1667. This period witnessed the decline of the republican Commonwealth and the return of kingship, which would signify to Milton both political and religious defeats: A political defeat when the English people abandoned the revolutionary republican system, upheld during the Civil War and the interregnum, and resumed conventional kingship, as well as a religious defeat when the republican system (which Milton would have considered a desirable realization of Protestant doctrines) failed. Given the intertwined defeats, $P L$ can be viewed as Milton's political and religious counterattack. Milton's religious endeavor is obvious in his clarifying the nature of God's providence and his justification of "the ways of God to man"; however, his political intention is rather subtle. Teskey contends that Milton must have wondered during the process of writing $P L$, "if God's plan for history is the increase of human liberty, partly by human means, partly by divine aid, what causes a nation to surrender its liberty” (2005, p. xxiii)? This report sees $P L$ as Milton's politico-religious counterattack against King Charles II's resumption of kingship and argues that the seed of Milton's political reform is built-into in his presentation of the psychological dynamics of Adam and Eve's fall; the tale highlights the significance of free will and the moral lessons of fortitude and patience. Additionally, this report further elucidates the comparison between Adam and Eve's fall and the fall of the republican Commonwealth as well as the way Milton's project of Protestant enlightenment seeks to carry out, by instilling in readers an alternate historical awareness, a re-shaping of the national consciousness of the 17th century English people.

\section{The Seed of Political Reform Built-into in the Presentation of Adam and Eve's Fall}

In his epic, Milton innovatively expands the biblical stories of Adam and Eve to highlight the significance of free-will. In fact, though the fall of Adam and Eve was of course well-known among Milton's contemporaries (virtually every household had a bible), the occurrence of the human fall is only vaguely depicted in the Genesis. As Danielson indicates, Milton brings this question "which Genesis leaves in the background" into "the foreground" (1989, p. 117). Milton's creative supplement to Genesis, according to Danielson, is an effort to resolve the long doctrinal debate of "God's foreknowledge and human free will” (p. 119). The debate is that if one's fate is fully predetermined by God's foreknowledge, there is no room for human free will; on the other hand, if human free will is believed to fully account for one's fate, it is a heresy since it challenges the omnipotence and omniscience of God. At that time, Calvinists and Presbyterians both reckoned "the unworthiness of the human creature and the bondage of the will" and underscored the idea of predestination and (Quint, 1993, p. 299). However, the emphasis on predestination, to Milton, would restrict people's taking responsibility of their own choice. As a result, Milton underlines the indispensability of human 
free will in $P L$ while presenting omniscient God.

To make room for human free will, Milton dissociates it from God's foreknowledge as a fait accompli, making it a verification of God's omnipotence and immutable good. Danielson (1989) recognizes a Boethian element in such dissociation (p. 120). The omnipresence of God is eternally present beyond human time, which is divided into the past, present, and future. Although one can see the cause of a present event as a fait accompli embedded in a chain of events extending back into the past and already known, foreseen, and hence intended by God beforehand, one can still recognize that one's free choice is responsible for the event. Human hindsight and God's omniscient foresight do not preclude the contingent moment of decision-making. This comparison shows one's tendency of ascribing one's hindsight to God's foreknowledge, but it does not mean one can fully comprehend God. After all, God signifies something always beyond as such. With this understanding, the very act of God's bestowing free will on humans and angels poses "a self-limitation on God's part”, further reinforcing the idea of God's omnipotence and immutable good (p. 117). God withholds force from humans and angels, but this does not contradict his omnipresent power. Instead, this shows his wholly benevolent nature since this suggests his belief in the ultimate victory of good over evil despite the potential destruction which would be caused by humankind's disobedience. Only with freedom can one truly show love, loyalty, and honesty towards God.

In Book Five, Milton's presentation of Adam and Eve, though foreshadowing their fall in Book Nine, is combined with some subliminal suggestions. Such presentation reveals Adam and Eve's potential to ascend and to fall in a prelapsarian state. Eve's dream, inspired by her having been tempted by Satan's voice, shows her propensity to fall. In the dream, Eve is led to the Tree of interdicted Knowledge and finds an angel extravagantly praising and soliciting her,

\author{
Happy though thou art, \\ Happier thou may'st be, worthier canst not be. \\ Taste this and be henceforth among the gods \\ Thyself a goddess, not to earth confined \\ But sometimes in the air as we! Sometimes \\ Ascend to Heav'n, by merit thine, and see \\ What life the gods live there-and such live thou! (Milton, 2005, p. 108)
}

On hearing the words, Eve senses that the "savory smell" of the forbidden fruit arouses her appetite, and Satan's rhetoric appeals to her vanity. So, she can’t help tasting the fruit (p. 108). The loss of her temperance in this dream goes along with the diminishing of her reason, foreshadowing her later act of transgression. In fact, the gods Satan suggests to put her among are fallen angels (Flannagan, 1993, p. 302). On the other hand, Raphael informs Adam of the possibility of their ascending to the heaven:

Attend! That thou art happy, owe to God.

That thou continuest such owe to thyself,

That is, to thy obedience: therein stand!

This was that caution giv'n thee. Be advised!

God made thee perfect, not immutable,

And good He made thee. But to persevere

He left it in thy pow'r, ordained thy will

By nature free, not overruled by fate

Inextricáble or strict necessity. (Milton, 2005, pp. 120-121) 
The sublimate remark is re-affirmed by God's words in Book Seven: There will be a union of Heaven and Earth as long as certain "obedience tried" (Milton, 2005, p. 163). Adam and Eve would be "thrice happy if they know / Their happiness and persevere upright!” (p. 176).

Though showing Adam and Eve's potentialities for both ascending and falling (in the moral sense), Milton needs to present the occurrence of their fall in a manner that justifies and explains God's providence. Raphael's warning them of the menace of Satan's coming is part of Milton's design and demonstrates God's foreknowledge and mercy. Before dispatching Raphael, God tells him that the will of humankind is free but "mutable”, and they should not feel "too secure [emphasis added]" living in an enclosed Eden (Milton, 2005, p. 112). Adam and Eve's current happy state, though based on their free will, does not preclude the danger of their becoming less free. To Milton, freedom is "never safe and never easy: freedom can be lost (by rebelling against God), and freedom demands discipline to resist the work of fate” (Teskey, 2005, p. 41). Furthermore, their fall would result not from external force, but from “deceit and lies” that test their inner force (Milton, 2005, p. 112). In other words, Adam and Eve should persevere in goodness both in obeying God's will and in avoiding any transgressions.

Satan is the first angel to rebel against God, and so doomed himself to futile attempts to revolt against God. God has conferred enough innate knowledge and reason on angels to stand upright on their own, so the fallen angels like Satan "ordained their fall” as a result of being "self-tempted, self-depraved” (Milton, 2005, p. 59). For example, Satan brags in front of his followers that they are "self-begot, self-raised" and calls for a rebellion against God for his own purpose (p. 130). While he is on his own, Satan confesses that God created him and that to "afford Him praise" is the "easiest recompense" (p. 79). In addition, Satan's courageous claim that the mind can voluntarily "make a Heaven of Hell, a Hell of Heaven” is actually a lie. Satan confesses where he is, there is Hell. By rebelling against God, Satan succumbs to his own demonic desires in an act of "infinite wrath and infinite despair” since he cannot outwit omnipotent God (p. 79). Though successfully causing humans' fall, Satan fails to foresee the offering of God's grace to the human descendants through Christ. While still in Hell, when Satan is about to accept the applause of the other demons for his achievement, they all, including himself, involuntarily turn into snakes, "with complicated monsters, head and tail” (p. 243). The image of snakes with heads and tails tied is an ancient image called Ouroboros, which can be dated back to Egypt. According to Flannagan, this image signifies "an endless Satanic circle” (1993, p. 553). Just as these fallen angels are turned into snakes annually, so they must undergo "an endless Satanic circle” of being defeated.

In the episode of Satan's first council, Milton carefully contrasts outward freedom and inward freedom. This council, similar to the one in Book Two, is conducted in a seemingly republican way. Satan poignantly indicts God's appointing the Son as the Lord of heaven when they are all equal,

Who can in reason then or right assume

Monarchy over such as live by right

His equals if, in power and splendor less,

In freedom equal? (Milton, 2005, p. 128)

Satan seems to urge a revolt against the monarchy of the Son, just as Milton did in his Tenure of Kings and Magistrates. The council is in fact conducted with a hidden agenda when Satan manipulates it through his subordinate Beëlzebub. Ironically, Satan is himself a monarch, who promises his people a freer state, which he is going to offer after having completed his agenda. In need of a train of attendants in this council, Satan 
demonstrates "an outward sign of his vanity and self-aggrandizement" (Flannagan, 1993, p. 337). Satan is subject to his own desires. On the other hand, the seraph Abdiel, "the Servant of God" in Hebrew, is the only one who dares to rise among the audience to point out the fallacy of Satan's remark. Satan is contradicting himself in talking of equality with a place already higher than his peers. Abdiel argues through the mediation of the Son, that they can access the Father more and "all honor to Him done / Returns our own" (Milton, 2005, p. 130). To put it somewhat differently, through the Word, they can praise God's benevolence, remind themselves of their own debt of happiness to Him, and then voluntarily follow goodness. Here, it is evident that through this comparison Milton highlights that Abdiel's perseverance and fortitude in upholding his faith, which true freedom relies on.

Compared to Abdiel, Adam and Eve are too innocent to withstand Satan's temptation, which is aimed at leading them towards violating their covenant with God. This covenant had been made between God and Adam: Not eating the fruit of the Tree of Knowledge symbolizes their obedience to God, and if they obey they can enjoy everything in Eden. The very act of eating will lead to their eventual death, which they can not fully comprehend. That is, though created free, they can't grasp the precariousness and responsibility of freedom until they fall. Adam is more aware of the dire consequences of the fall than Eve, because he has been informed by Raphael. Raphael reveals that angels and humans both reason intuitively and discursively, though in different degree: "Discursive or intuitive: discourse / Isoftest yours, the latter most is ours, / Differing but in degree, of kind the same” (Milton, 2005, p. 119). Humans tend to think discursively while angels intuitively. Yet, Adam and Eve fall for different reasons.

Eve falls because her idea of happiness, or being free, is based on the "all" or "none" of security. In Book Nine, Eve suggests they labor separately, but is reminded of the danger of being tempted alone by the foe. Eve justifies her insistence on fighting against the foe alone as a means of verifying her faith: "what is faith, love, virtue unassayed, / Alone, without exterior help sustained?” (p. 206). This may remind us of Milton's contention in Areopagitica, that virtue which has not been tested by the trial of evil is "a blank virtue" (p. 350). It is quite easy to see how eager Eve is to prove her worth as equal to Adam, for she has felt inferior to him time and again. Yet, it is problematic that Eve's confidence in her faith is based on the mistaken thinking that their current happy state in Eden is guaranteed by God. When urging Adam, Eve asserts,

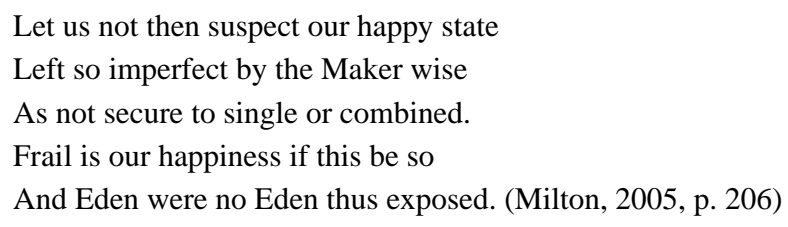

In other words, Eve naively attributes security solely to God; she cannot grasp the power of evil. Eve is holding God responsible for the security of Eden. This is a Calvinist stance. According to Quint's observation, a Calvinist believer needs assurance of being "among the predestined elect", and this would deprive him or her of taking the responsibility of choosing to persevere or to fall (1993, p. 284). In this regard, Eve fails to see that the security of their current happy state, as Adam points out, is based on "outward force", that is, the cloistered state of Eden. They have to apply their reason to resist any temptation on their own: When God has done his part and Eve has to do her part. Mistaking Adam's pleading of her to continue to persevere for acquiescence in her desire to go off on her own, Eve leaves him alone and is unaccompanied when tempted by Satan in the disguise of the snake. Eve mistakes freedom for the ends, not the means. In credulously trusting Satan when he 
suggests she can achieve a freer and higher state than Adam by eating this forbidden fruit, Eve plucks and quickly eats the apple.

While Eve falls due to her hope for a happier state she believes the forbidden fruit will bestow, Adam falls due to the image of himself he projects upon her. To Adam, Eve appears to possess the image of "self-sufficiency" he lacks. Since Eve is made from a rib God had taken from him, that image can mean the part of himself Adam desires to possess. Adam's lack of self-esteem is revealed in his account of Eve to the angel Raphael. Intellectually, Adam can perceive his superiority over Eve. Emotionally, Adam can’t but feel inferior to her since she seems to be as complete a being as God and in front of her, knowledge and wisdom seem to fall short:

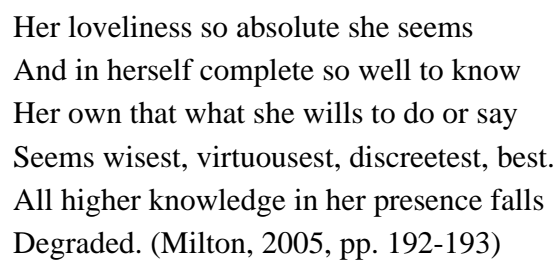

When comparing Eve to God in the sense of self-sufficiency, Adam is showing his anxiety of being in a middle position between God and other creatures, which seems no problem at all to Eve. As a result, when Eve is determined to work alone, Adam is over-confident regarding Eve, who seems so perfect that "no evil durst attempt” her, according to Adam’s retrospective confession (Milton, 2005, p. 229).

\section{Milton's Ongoing Project of Protestant Enlightenment}

The fall of both Eve and Adam can be seen as the result of the inferiority complex, attributing "the doctrine of assurance” to others, instead of themselves (Quint, 1993, p. 299). In fact, Milton implicitly suggests that due to the English people's lack of confidence, especially the orthodox and Presbyterian adherents, they had restricted the freedom of "the Church" and "civil political organizations", and thus impaired the operation of republican Commonwealth (Quint, 1993, p. 296). Their belief in predestination and assurance is in contrast with Milton's liberal idea of a "free state" since these adherents recommend a strong coercive Church government to grant certain people assurance of salvation. According to Quint, Milton disagrees with a coercive state intervention in church discipline. Cromwell's later politics tends to reinforce itself through his playing the role of the Lord Protector who assures salvation while actually limiting religious liberty. To Milton, such an assurance should come from one's inward persuasion in acting in accordance with God's promises or covenants, not an outward guarantee. Cromwell's very act resembles what previous kings did, though Arminians, like Milton, attempted to facilitate a liberal climate in the republican Commonwealth. Fearing that the Commonwealth would become politically unstable, the contemporary English people hastily returned to the security offered by conventional kingship, inviting Charles II to return and rule over them, just as Eve hastily chose to seek security from Satan as outward assurance and then fall. The defeat of the Commonwealth for the English people is compared to the loss of Eden for Adam and Eve.

Seeing himself in a fallen state as both a human and a protestant republican, Milton re-introduces the fall of Adam and Eve for the English, using it as a metaphor he hoped would awaken them to their political folly and cause them to repent their jettisoning of the Commonwealth and, perhaps, recuperate its vision. The nation needed to go through a psychological purgatory through reading history from an apocalyptic viewpoint. The 
interrelationship between secular time and celestial time is a clever trick Milton devises to help his contemporaries develop an alternative historical sense that would enable them to re-imagine the recent political events and perhaps even mediate the religious politics he desired. Milton offers his critique of kingship in Book Twelve. Through the angel Michael's revelation, Adam learns to see human history as a cyclical process of being punished for wicked deeds and being redeemed through repentance. Adam's offspring will live under a series of tyrannical ruling systems. Nimrod, as the first monarch after the flood, represents a type of Satan whose "outward freedom” enthralls his followers (Milton, 2005, p. 287). Those followers are driven by passion rather than by reason and so are deceived by this promise of outward freedom, and develop the habit of inward servitude; they obey his will and build the Tower of Babel, thus transgressing the omnipotence of God. They are all punished. Here, Milton actually alludes to the Stuart kings who usurp power from God to rule their equals.

Despite mankind being oppressed by tyranny, Milton then associates the English people with the ancient Hebrews to deliver his idea of secular politics under the guidance of a sacred promise. Milton compares the wandering of the Hebrews in the desert with the drifting of the English people through the trials of civil war, suggesting that like the Hebrews, the English must develop laws to help themselves know their sins, avoid wrongdoing and try to govern themselves. Under the Law mediated by Moses, "Their government and their great senate choose / Through the twelve tribes to rule by laws ordained” (Milton, 2005, p. 291). Milton further separates Moses from Joshua to differentiate politics from ethics. It is only through Joshua that the Hebrews could finally be led to the Promised Land, Canaan. Likewise, it is only through the coming of Jesus, symbol of God's grace, that the humans can be granted salvation. The suffering of wandering in the desert is necessary for the Hebrew people to await Joshua and prepare to enter the Promised Land. Similarly, the English people must suffer through the process of forging a set of laws and the building of a republican system that can help prepare for the crowning of a rightful King. This differentiation is essential since the close cycle of endless downfall throughout human history, just like Satan's self-defeating circle, is turned into a suspension of humans' free choice as the possibility of spiritual progress toward the after-life in the coming Last judgment. Through the Son's sacrifice, those who follow his teaching will be redeemed in the end.

\section{Conclusion}

Although Milton does not believe his project of Protestant Enlightenment can be actualized by the continuation of the Commonwealth, he manages to re-shape the national consciousness of the 17th century English people through an alternate historical awareness, an awareness of salvation to come. Milton seems to urge his fellow English citizens to hold onto the republican idea and patiently await the right leader to come. Adam and Eve were banished from Eden, and they had to choose where their place of rest would be and trust Providence to be their guide. In like manner, the English must realize that happiness in the contingency of life can be only attained through following their vigilant conscience, enduring undesirable conditions and waiting for the right moment to come, just as did Milton himself.

\section{References}

Danielson, D. (1989). The fall of man and Milton's theodicy. In D. Danielson (Ed.), The Cambridge companion to Milton (pp. 113-130). Cambridge: Cambridge University Press.

Flannagan, R. (Ed.). (1993). John Milton: Paradise Lost. New York: Macmillan.

Milton, J. (2005). Areopagitica. In G. Teskey (Ed.), Paradise lost (pp. 339-374). New York: Norton. 
Milton, J. (2005). Paradise lost. In G. Teskey (Ed.), Paradise lost (pp. 1-303). New York: Norton.

Quint, D. (1993). Paradise Lost and The fall of the English Commonwealth. In Epic and empire: Politics and generic form from Virgil to Milton (pp. 268-324). Princeton: Princeton University Press.

Stevens, P. (2001). Milton’s Janus-faced nationalism: Soliloquy, subjectivity, and the modern nation state. Journal of English and Germanic Philology, 100(2), 247-268.

Teskey, G. (Ed.). (2005). Introduction: The life of John Milton. In Paradise lost (pp. xv-xxx). New York: Norton.

Walker, W. (2006). Resemblance and reference in recent criticism on Paradise Lost. Milton Quarterly, 40(3), 189-206. 